\title{
PEREMPUAN DI PERSIMPANGAN JALAN DARI REFORMASI
}

(Women at the Crossroads of Reformation)

\section{Mariani Febriana Lere Dawa}

\begin{abstract}
Abstrak: Merayakan Reformasi Gereja yang ke-500 tahun pada tahun ini tidaklah menjadi lengkap tanpa mendiskusikan peran perempuan dalam perjuangan Reformasi. Tradisi mencatat banyak hal yang berkaitan dengan laki-laki dalam Gerakan Reformasi, namun sedikit yang membuka tabir tradisi di baliknya mengenai peran perempuan. Karena itu, artikel ini memberikan catatan sejarah yang tersembunyi mengenai peran perempuan dan menunjukkan betapa kontribusi perempuan dalam penyebaran ideide Reformasi tidak dapat diabaikan.
\end{abstract}

Para perempuan dari kalangan bangsawan dan juga para istri pendeta dari gereja Protestan memberikan diri mereka dengan keunikan masing-masing dalam tugas panggilan mereka. Mereka dengan berani dan dengan rela menyerukan suara Reformasi ini, sekalipun kematian menjadi ancaman bagi mereka. Bagi para perempuan tangguh dalam Reformasi ini, tidak ada kata lain selain Kebenaran Injil diberitakan.

Bergerak dari Jerman, menuju Strasbourg, Perancis, Jenewa, dan Inggris, beberapa perempuan yang disebutkan di sini adalah mereka yang sudah menyuarakan suara mereka dalam era dan waktu mereka. Karena itu, bersama dengan mereka pada hari ini, mari kita menyerukan suara kebenaran ini sembari menyadari hakekat dan karunia diri kita masing-masing, agar berita Injil tersebar ke semua penjuru. 
Kata-kata Kunci: Reformasi, peran perempuan, hakekat dan karunia, istri, dan pejuang kokoh

Abstract: Celebrating the uprorious time of $500^{\text {th }}$ years of the Reformation cannot be fully explained without discussing on women's role in the Reformation Movement. The hidden tradition of women's role in the Reformation is worthy to be drawn out. Much writings on Reformation was always linked to men. Nonetheless, we cannot ignore the great role of women in Church Reformation. Reformation, in some ways, has influenced women in their role and calling. History has noted that many women have given so much important contributions in the Reformation Movement. Therefore, this article attempts to reveal this hidden tradition on how women in their gifts and lives have they committed for the sake of Reformation to be widely accepted in Europe.

Noble and educated women that have sympatized with Reformation's ideas working hand in hand in spite of the great risks that had laid before them. Some of them are pastor's wives, queen, and noble women. They act themselves as a wife, public speaker, writer, diplomat, theologian and counselor. They give much their efforts on fighting gently on what they thought the way it should be as they learnt from the Bible and the Church Reformers. They come from all Europe and they have one voice that nobody should deny their gifts and calling in the ministry of the Gospel without neglecting their nature and identity as a woman. In their time and places, they have proved themselves as the godly women of their time. Therefore, let us join them to voice the treasure of the gospel today and to improve and enrich the life of the church and society by acting out our role gently and passionately according to our gifts and calling. 
Keywords: Reformation, women's role, nature and gift, wife and strong defender of Reformation

\section{PENDAHULUAN}

Merayakan gegap gempita Reformasi yang ke-500 tahun pada tahun ini tidak akan menjadi lengkap dalam perarakan iman gereja tanpa mendiskusikan peran perempuan di dalamnya. Capern menegaskan, "The seismic cultural shift of the Reformation cannot be fully explained without reference to women." Banyak dari para pembaca sangat lazim dengan nama-nama laki-laki dari era Reformasi. Namun sedikit yang mengenal perempuan dalam Reformasi. Padahal gerakan Reformasi abad ke-16 paling tidak sudah memberikan dampak positif bagi perempuan. Bahkan perubahan sosial yang terjadi di dalam Reformasi sebaliknya mengubah posisi dan peran perempuan selanjutnya. Dengan menyingkapkan tradisi tersembunyi dari para perempuan dalam Reformasi, maka kita akan mendapatkan inspirasi bukan hanya soal kepedulian dan pembinaan rohani kepada perempuan namun juga kita akan menemukan peran, konsep diri, nilai, dan martabat perempuan dalam tradisi Protestan mula-mula.

Reformasi sekaligus menjadi gerakan pendidikan bagi perempuan untuk aktif secara teologis dan mengevaluasi kembali wilayah kehidupan dari perempuan yang selama ini terpisah dari dunia dan terpusat pada pembiaraan. Reformasi juga menegaskan peran perempuan sebagai ibu dan istri. Kelompok perempuan yang menerima dampak yang luar biasa dari gerakan ini secara khusus adalah para perempuan bangsawan dan juga para istri dari Reformator. $^{2}$

\footnotetext{
${ }^{1}$ Amanda Capern, The Historical Study of Women: England 1500-1700 (Basingstoke, UK: Palgrave Macmillan, 2010), 4

${ }^{2}$ Barry McWilliams, Women of the Reformation, di akses dari www.eldrbarry.net /heidel/wivesref.pdf, tanggal 21 Juni 2017.
} 
Para perempuan bangsawan ini banyak memberikan pengaruh dalam terjadinya peristiwa Reformasi, khususnya para istri dari Henry VIII dengan segala kompleksitas politik di dalamnya, Mary Tudor; Elizabeth I, Mary Stuart, Ratu dari Skolandia. Ada juga Marquerite of Navarre dan Jeanne d'Albret, Renée de France, yang membela kelompok Protestan Perancis, Olimpia Fulvia Morata, dari Italia, Charlotte of Bourbon dan Louise de Coligny di Belanda. Para istri Reformator sangat berpengaruh dalam Reformasi, khususnya dalam kehidupan rumah tangga mereka, yang pada gilirannya menjadi model bagi masyarakat dan secara perlahan-lahan mengubah budaya Eropa, secara khusus pernikahan yang dahulunya dianggap sebagai suatu kepemilikan/property daripada relasi kasih bersama.

McWilliams juga menjelaskan mengenai persentasi dari kehidupan pada abad itu kebanyakan adalah petani yang tinggal di desa, sepuluh persen adalah kelompok kelas menengah, pedagang, penduduk kota dan sisanya lima persen adalah kaum rohaniwan dan bangsawan. Rata-rata usia mereka adalah tiga puluh tahun untuk laki-laki dan dua puluh empat tahun untuk perempuan, di mana mereka yang mencapai usia empat puluh tahun sudah dianggap tua. Perempuan rata-rata memiliki enam atau tujuh anak jikalau mereka berhasil melewati masa melahirkan. Hampir ratarata empat puluh persen hingga lima puluh persen anak-anak umumnya mati sebelum usia dua belas tahun dan hampir sepuluh persen laki-laki tidak pernah menikah. Hampir dua belas persen perempuan tinggal di biara. Jikalau tidak menikah dan membiara, ada sedikit perempuan yang melakukan tindakan prostitusi. Dalam kelas atas, nasib para gundik lebih baik dari seorang istri. Di Eropa bagian utara, keluarga dipusatkan pada pasangan yang menikah, dan di bagian selatan rumah tangga mencakup satu pasangan dan 
anak-anak mereka yang menikah dan cucu-cucu mereka tinggal bersama. $^{3}$

\section{REFORMASI DAN PEREMPUAN}

Pertanyaan penting berkaitan dengan Reformasi di sini adalah apakah Reformasi memberikan kemungkinan baru kepada perempuan dalam peran kepemimpinan dan menggunakan pemikiran teologis mereka di arena publik atau memang Reformasi membatasi pilihan-pilihan perempuan? Bagaimana dengan pengajaran Protestan mengenai keimamatan semua orang percaya diaplikasikan kepada perempuan? Apakah memang teologi Protestan mempromosikan persamaan rohani dan emansipasi dalam semua hal termasuk persoalan perempuan? Jawaban dari pertanyaan-pertanyaan ini menurut Stjerna masih ditemukan sangat ambigu, karena pada satu sisi benih dari emansipasi radikal sudah melekat dalam pengajaran Reformator, pembenaran oleh iman sebagai pemberian Allah kepada manusia tanpa memperhitungkan perbuatan manusia. Karena itu keimamatan orang percaya merupakan ekspresi alamiah dan dasar dari persamaan rohani.

Di sisi lain, suara perempuan secara kolektif dan sangat sedikit catatan yang didokumentasikan tentang pendapat perempuan terhadap gerakan ini sangat minim. Minimnya tulisantulisan ini karena memang posisi sosial dan kelas sosial sangat memengaruhi aktivitas religius perempuan pada masa itu, secara khusus setengah abad pertama dari abad keenam belas. Hanya mereka dari kelas atas saja yang punya kesempatan ini. Di samping itu sedikit sekali para perempuan dalam pemulaan era modern yang mengecap pendidikan, atau kecukupan dana untuk menulis atau

\footnotetext{
${ }^{3}$ Barry McWilliams, Women of the Reformation, di akses dari www.eldrbarry.net /heidel/wivesref.pdf, tanggal 21 Juni 2017.
} 
menerbitkan karya mereka, jikalau mereka bukanlah sahabat atau rekan dari kalangan bangsawan. ${ }^{4}$

Namun itu tidak berarti tidak ada respon dari para perempuan terhadap Reformasi, sekalipun ada kesan perempuan pada masa itu sangat terpesona dengan berita yang luar biasa itu dan belum sempat memberikan respon apa arti berita itu bagi perempuan secara khusus. ${ }^{5}$ Beberapa bukti menunjukkan bahwa ada beberapa perempuan yang menulis pasca Gerakan Reformasi khususnya pada tahun 1545 Duchess Elisabeth von Braunschweig-Lüneburg menulis ke anak laki-lakinya Erich tentang gaya hidup religius. Tulisan yang diterbitkan pada abad ke-16, ditulis dengan dorongan kala mereka membaca tulisan Luther mengenai imamat orang percaya yang sudah dibaptis, yang mendorong individu menemukan pesan yang membebaskan baginya dalam Kitab Suci tanpa harus datang terlebih dahulu kepada imam atau rohaniwan untuk membaca Kitab Suci. Perempuan juga menulis himne, katekismus, literatur, dan karya dogmatis serta beberapa dari mereka sangat aktif menulis karya teologis, di antaranya Argula von Grumbach, yang aktif mempertahankan Reformasi di Bavaria, dan Magdalene Heymar dari Augsburg yang adalah seorang guru. ${ }^{6}$

Reformasi membawa perspektif baru dalam spiritualitas dan vokasi perempuan dalam dunia, di tengah pengajaran bahwa perempuan itu seharusnya berdiam diri dan peran ketundukan perempuan dalam gereja, serta secara institusi melarang perempuan mengajar, berkhotbah, dan mengambil peran publik. Dalam situasi

\footnotetext{
${ }^{4}$ Carol Thysell, The Pleasure of Discerment: Marguerite De Navarre as a Theologian (Oxford: University Press, 2000), 4.

${ }^{5}$ Kirsi Irmeli Stjerna, Women and the Reformation (Oxford: Blackwell Publishing, 2009), 11.

${ }^{6}$ Ute Gause, The Reformation war an educational movement for women, too (diakses dari https://www.luther2017.de/en/wiki/women-move-the-church-since-luthers-time/thelong-way-to-pastoral-ministry-women-in-the-age-of-the-reformation), tanggal 22 Juni 2017.
} 
demikian, muncul para perempuan dalam sejarah yang menembusi aturan-aturan gender yang sudah membatasi karya dan aktivitas perempuan dengan mengambil peran menjadi guru, penulis, dan pemimpin, secara khusus Marguerite de Navarre dan putrinya Jeanne d'Albret, dan rekannya Renée de France yang mengambil langkah berani melindungi kelompok Hugenot. Demikian juga Katharina Schütz Zell, istri dari Matthew Zell (Imam Katholik yang menjadi pendeta Lutheran) dan Argula von Grumbach menulis karya toleransi beragama dan bertindak demi mereka yang tertindas karena kepercayaan mereka. $^{7}$

Di sisi lain, hal yang menarik justru terjadi dalam Reformasi agama di Inggris dalam era Henry VIII (28 Juni 1491-28 Januari 1547) yang sarat dengan muatan politis dalam keterpisahan Gereja Inggris dengan Gereja Katholik Roma. Dalam Reformasi agama di Inggris, respon perempuan, khususnya dari kalangan atas sangat mewarnai Reformasi di negara ini, dengan perhatian utama pada identitas gender. Dalam diri para perempuan ada suatu kehilangan mendalam tentang ikatan mereka satu sama lain yang mereka bangun dalam hidup membiara guna menapaki jalan kepada sang Ilahi dan kelegaan dari peran sosial yang bersifat tradisional bagi perempuan sekarang dileburkan ke dalam rumah, dan karena itu sarana untuk identitas gender dan agama mereka tidak ada lagi. Persoalan penting timbul di sini bagaimana sekarang perempuan mendefinisikan dirinya berhadapan dengan agama yang kolaps dan jarak sosial yang ada? Suatu batasan diberikan oleh Reformasi yang pada akhirnya memaksa perempuan untuk bernegosiasi bagi diri mereka sendiri. ${ }^{8}$

\footnotetext{
${ }^{7}$ Stjerna, Women and the Reformation, 17.

${ }^{8}$ Julie A. Chappell and Kaley A, Kramer, ed., Women during the English Reformations: Renegotiating Gender and Religious Identity (New York: Palgrave Macmillan, 2014), 1-9.
} 
Terlepas dari pada perubahan dalam dunia pada masa itu, khususnya peran perempuan dalam hidup mereka, penolakan Reformasi terhadap cara hidup membiara justru menyebabkan perempuan kehilangan kesempatan penting dalam formasi rohani dan vokasi secara umum. Namun ironinya kehilangan ini justru mempertemukan mereka pada realita yang baru di mana harkat baru dari peran mereka kini diperluas berkaitan dengan pengaruh sosial dan rohaninya dalam dunia melalui keluarga, di mana pernikahan menjadi ruang dari vokasi kudus mereka. Bahkan tidak ada opsi lain yang menerima berkat teologis ini selain pernikahan. Karena itu teolog Reformasi membawa perempuan kembali ke rumah sebagai ibu dan istri, dan ini justru menjadi panggilan mereka yang mulia. ${ }^{9}$ Pertanyaan dasar di sini adalah apakah penekanan pada pernikahan (sebelumnya penekanan pada keperawanan) selama era Reformasi abad ke-16 meningkatkan status dan pendayagunaan perempuan Kristen? Pertanyaan ini penting karena memiliki implikasi bagi perempuan dalam kekristenan, khususnya perempuan dalam agama karena hal ini menembus inti dari keadaan manusia. ${ }^{10}$

Sebagaimana sejarah mencatat di atas, memang penekanan Reformasi adalah pernikahan, dengan tujuan membawa perempuan dalam perspektif baru bahwa pernikahan itu juga adalah panggilan kudus yang tidak bisa diabaikan. Artinya, peran perempuan dalam rumah rumah tangga menjadi hal penting juga. Sekalipun Reformasi menekankan pernikahan, namun tampak juga panggilan perempuan semakin meluas bukan hanya dalam keluarga, namun

\footnotetext{
${ }^{9}$ Kompleksitas isu yang bercampur dengan situasi politik dan kehidupan beragama terus mengalami perkembangan berpikir yang pada akhirnya mengajak gereja berpikir ulang kembali tentang realita dan hakekat sebenarnya dari laki-laki dan perempuan, dan pernikahan serta khususnya meningkatnya kehidupan lajang di zaman modern ini. Lihat tulisan saya Lajang dalam Gereja di Jurnal Aletheia yang dapat diakses dari http://sttaletheia.ac.id/wp-content/uploads/2015/04/LAJANG-DALAM-GEREJA-DANPELAYANAN-Pdt-Mariani-Febriana.pdf.

${ }^{10}$ Rebecca Moore, Women in Christian Tradition (New York: New York University Press, 2015), 2.
} 
juga dalam ruang publik. Pengakuan akan peran dari gender yang tidak dapat dihindari dan menyebar dalam hidup manusia dan sejarah menegaskan bahwa tidak ada sejarah atau teologi yang merupakan buta gender atau netral, tepat sama seperti tidak ada teologi atau sejarah yang non kontekstual atau tanpa wajah manusia. Membaca hal ini sangat penting agar terhindari dari kesalahpahaman konsep terhadap Reformasi, yang seolah-olah mengurung perempuan dalam rumah dan mengabaikan kemampuan dan aktualitas diri mereka. Meskipun akhirnya resiko yang tidak dapat dihindari adalah sikap dari Reformasi ini kemudian dibaca secara berlebihan dalam zaman modern, seolah-olah perempuan yang menikah itu memiliki status yang lebih baik dan yang tidak menikah itu dianggap lebih rendah.

Perlu dipahami juga bahwa perempuan yang hidup dalam biara pada Abad Pertengahan adalah cara mereka menemukan diri mereka di tengah situasi sosial yang tidak mudah bagi mereka. Penemuan diri dalam biara menjadi hal yang sangat menyenangkan selama kurun waktu yang panjang, sehingga ada suatu rasa kehilangan yang dalam kala pembiaraan itu dihapuskan. Namun menariknya, penekanan Reformasi pada pernikahan tidak mengabaikan pola pendidikan biara yang sudah berlangsung selama bertahun-tahun khususnya bagi para perempuan. Para Reformator merasa bertanggung jawab untuk pengembangan dan aktualitas dari para perempuan dan anak-anak perempuan dengan mengakomodasikan hal yang dianggap terhilang dalam Reformasi, yaitu dengan mengembangkan pendidikan bagi kaum perempuan dalam gereja yang disebut Virgin schools dan para pengajarnya adalah perempuan. ${ }^{11}$ Sekalipun tingkatan dari pola pendidikan ini berbeda dengan pola pembiaraan bertahun-tahun untuk pengembangan spiritualitas dan intelektual perempuan. ${ }^{12}$

\footnotetext{
${ }^{11}$ Ute Gause, The Reformation war an educational movement for women, too.

${ }^{12}$ Stjerna, Women and the Reformation, 41-42
} 
Berkenaan dengan peran perempuan dalam Reformasi sebagaimana Douglass menyebutkan bahwa pemikiran Calvin mengenai tata sosial bukanlah statis, kaku, sistem yang ketat, melainkan diakarkan pada ketetapan Allah, suatu ekspresi dari kehendak Allah, yang dinyatakan dalam berbagai macam bentuk dalam era dan budaya yang berbeda. Artinya, ada hal yang berkaitan dengan tradisi kepantasan dalam tata aturan sosial, dan bukan soal doktrin, sehingga implikasinya bisa beraneka ragam. Hal ini penting karena memang agama dan kekudusan tidak terletak pada soal yang lahiriah, melainkan pada prinsip normatif dari kehendak Allah untuk membawa tujuan Allah dalam dunia, sekalipun hirarki ciptaan tidak bisa diabaikan dan karena itu perempuan dengan rela hati menerima kuk ini hingga kedatangan kerajaan Allah. $^{13}$

Beranjak dari pemikiran di atas, maka pernikahan dianggap sebagai panggilan religius tertinggi bagi perempuan untuk memenuhi peraturan Allah dan menebus efek dari kejatuhan, dan karena itu identitas perempuan dan panggilan mereka ditarik dari alasan dasar untuk keberadaan mereka, menolong dalam melahirkan, penolong bagi pria, mengatur rumah tangga dan menolong untuk mengatasi keinginan yang menyimpang. ${ }^{14}$ Memang pada era Protestan mula-mula, para laki-laki di Eropa lebih cenderung mengasosiasikan perempuan untuk berdiam diri, tunduk dan taat, namun kondisi ini perlahan-lahan juga berubah seiring dengan perkembangan era modern. Menariknya, hal yang baru dari pemikiran Reformator ini mengenai pernikahan dan peran perempuan dalam konsep tersebut di atas lebih nampak dalam peran baru dari istri pendeta, karena memang peran istri pendeta pada masa itu adalah hal yang sangat baru. Jadi penekanan

\footnotetext{
${ }^{13}$ Jane Dempsey Douglass, Women Freedom and Calvin (Philadelphia: Westminster Press, 19850), 33-41.

${ }^{14}$ Stjerna, Women and the Reformation, 34-35.
} 
perjuangan dalam Reformasi berhadapan dengan situasi sebelumnya kini lebih menekankan penikahan dan peran perempuan sebagai istri dan ibu bagi keluarga dan jemaat.

Peran dari istri pendeta menghadirkan suatu idealisme khusus bagi perempuan dan keluarga dan peran agama dan sosial mereka sebagai role model bagi keluarga kristen. Berikut di bawah ini akan dibahas perempuan-perempuan tangguh dalam Reformasi, khususnya peran yang mereka bawa dalam memperluas Reformasi.

\section{PARA PEREMPUAN YANG MEMBERIKAN KONTRIBUSI DALAM REFORMASI}

Secara umum, para perempuan dalam Reformasi adalah mereka yang hidup dalam pernikahan. Sebagaimana ditegaskan di atas bahwa peran perempuan dalam pernikahan tetap diperluas dalam memberikan dampak bagi kehidupan publik. Adapun beberapa dari mereka adalah:

\section{Katharina von Bora (1499-1552)}

Katharina memberikan kontribusi yang luar biasa dalam Reformasi sebagai seorang pasangan, partner, dan penyeimbang dari seorang tokoh agama besar pada masanya. Dia meletakkan model panggilan dalam berbagai macam dimensi bagi seorang perempuan, seorang istri, dan seorang ibu. Kepribadiannya, karunia-karunia, dan kesadaran dirinya serta tujuan diri menjadikannya pasangan yang luar biasa dari Martin Luther.

Dilahirkan dalam keluarga bangsawan dan hampir dua puluh tahun mengecap hidup membiara, di mana lima belas tahun hidup dalam biara Cistercian dengan empat puluh biarawati dari latar belakang keluarga bangsawan, Katharina belajar hal-hal penting di 
biara khususnya formasi rohani, disiplin dan kebiasaan rohani, mengatur diri, menyanyi, seni berdoa, dan membaca Kitab Suci. Karena keterampilannya dalam membaca maka dia dapat memahami tulisan-tulisan Luther, apalagi dia berkawan akrab dengan para perempuan yang berpendidikan tinggi pada masa itu, yaitu Magdalena von Staupitz, saudara perempuan dari Johann von Staupitz, dan Elsa von Canitz, di mana keduanya adalah guru di sekolah perempuan di Wittenberg. Memiliki latar belakang yang baik karena dari keluarga bangsawan dan pendidikan biaranya menjadikan Katharina sebagai perempuan yang memiliki gambar diri yang baik yang pada akhirnya ditampilkan dalam hidupnya di Wittenberg, tempat di mana suaminya, Luther, berkarya dan melayani.

Katharina von Bora meninggalkan pembiaraan karena membaca tulisan-tulisan radikal Luther mengenai kehidupan monastik yang dianggap bertentangan dengan kitab Suci, meskipun tidak mudah menelusuri bagaimana Katharina dan para biarawati Cistercian mendapatkan tulisan Luther tersebut. Yang jelas tulisan Luther memberikan persuasi intelektual yang luar biasa yang membuat para biarawati, termasuk Katharina, keluar dari biara di Nimbschen. ${ }^{15}$

Dalam tahun-tahun awal pernikahan mereka penuh dengan tantangan karena mereka adalah pasangan biarawan dan biarawati pertama yang menikah, pasca kehidupan membiara yang panjang, selain Katharina Schütz Zell, yang menikahi seorang imam Matthew Zell di Strasbourg. Gosip dan rumor karena pernikahan mereka benar-benar menyerang mereka. Bahkan ketidaksetujuan datang dari Melanchton dan tuduhan dari Erasmus tentang pernikahan ini, meskipun pada akhirnya mereka menarik tuduhan

\footnotetext{
${ }^{15}$ Michelle DeRusha, Katharina and Martin Luther: The Radical Marriage of a Runaway Nun and a Renegade Monk (Grand Rapids: Baker Book Ho, 2017), 106-107.
} 
mereka terhadap Luther dan Katharina. ${ }^{16}$ Namun kekokohan cinta mereka menjadikan mereka bertahan melawan serangan-serangan dalam pernikahan mereka. Bahkan Luther tidak ragu menyebutkan istrinya sebagai Morning Star of Wittenberg, ${ }^{17}$ karena bangun setiap hari jam 4 pagi agar supaya dapat menyelesaikan pekerjaan rumahnya hingga jam 9 malam. ${ }^{18}$ Mereka dikaruniai enam anak, dan ada tujuh keponakan dan empat anak yatim piatu dan beberapa orang lagi yang tinggal bersama di rumah dengan mereka.

Katharina menjadi penolong luar biasa bagi Luther. Sebelumnya para sekutu dan penasehat Luther menganggap bahwa Katharina dapat menjadi penghalang dalam karir Luther, namun pendapat ini berbalik setelah menyaksikan bukti nyata bahwa Katharina memberikan dampak positif bagi kesehatan fisik dan mental Luther. Rasa takut dari sahabat-sahabat Luther berubah menjadi pujian kepada Katharina dan dia menjadi bagian yang menyatu dalam karir Luther yang sukses. ${ }^{19}$

Sebagi seorang istri Reformator, Katharina menjadi model melaksanakan panggilan teologis dari seorang istri secara umum dan istri dari seorang pendeta dan dosen. Luther dalam hal ini menyebut istrinya sebagai teolog, pengajar, istri tersayang Katharina von Bora, pengkhotbah, pemasak bir, tukang kebun, dan apa saja dia bisa. Katharina mengajar dan berkhotbah bagi keluarganya, sahabat, para pengunjung yang datang ke rumahnya, yaitu jemaatnya dengan memberi makan, merawat, memberi pakaian, mengasihi, dan mendisiplinkan sebagai bagian dari devosi dirinya untuk menolong pasangannya. Dia banyak melakukan pekerjaan rutin sehingga banyak membantu Luther bisa fokus pada pelayanannya. Partisipasinya dengan cara ini dalam pelayanan

\footnotetext{
${ }^{16}$ DeRusha, Katharina and Martin Luther, 104.

${ }^{17}$ Stjerna, Women and the Reformation, 57.

${ }^{18}$ DeRusha, Katharina and Martin Luther, 110.

${ }^{19}$ Ibid., 114.
} 
Luther dan menjadikan gereja baik dalam keadaannya melalui pelayanan rumah ini adalah sangat penting dan menjadi model bagi para istri pendeta yang menolong suaminya melakukan pekerjaan mereka, paling tidak bertanggung jawab dalam mengelola kehidupan di rumah, dan menjadi model bagi tempat untuk pelayanan Protestan. Dari tempat itu, para istri pendeta melayani dalam misi yang lebih luas dari gereja. ${ }^{20}$

Katharina terbiasa dengan bahasa teologi dan isu-isu penting pada masa itu dan mendiskusikannya di meja makan. Dia mendevosikan energinya dalam wilayah domestik rumah tangga, di mana dia muncul sebagai pemimpin dan teladan dari ibu yang efisien dan seorang istri dari Reformator. Dia mengubah dirinya dari idealisme perempuan Kristen Abad Pertengahan, yaitu seorang biarawati yang luar biasa menjadi suatu model bagi perempuan Protestan dalam perannya sebagai istri dan ibu di samping Luther. Perannya membawa dimensi domestik dari keimamatan orang percaya dan kekudusan dari panggilan, secara khusus pengasuh bagi anak-anaknya dan melepaskan ambisinya di luar rumah dan di rumahlah dia berkarya, karena itu di situlah panggilan dirinya dilakukan. Mimbar gereja, kuliah di universitas dan persoalan publik menjadi tanggung jawab suaminya, namun urusan peran mereka sebagai orang tua sama-sama mereka lakukan bagi anak mereka di rumah. ${ }^{21}$

Katharina merupakan figur penting dari seorang istri yang berkomitmen untuk mendukung Reformasi dan pada ranjang kematiannya, dia menyerukan iman dari seorang Lutheran dengan penuh percaya, "I will stick to Christ as a burr to a top coat.",2

\section{Katharina Schütz Zell (1497-1562)}

\footnotetext{
${ }^{20}$ Stjerna, Women and the Reformation, 59-60.

${ }^{21}$ Ibid., 69.

${ }^{22}$ Stjerna, Women and the Reformation, 67.
} 
Dilahirkan dalam keluarga biasa namun cukup terpandang dalam masyarakat, Katharina mengecap pendidikan yang baik, sekalipun dia tidak sempat belajar bahasa Latin secara khusus. Selama bertahun-tahun dia dihormati sebagai ibu dari gereja di Strasbourg, di tengah situasi di mana kepemimpinan gereja menjadi hak prerogatif laki-laki. Dalam suatu masyarakat di mana istri yang baik itu harus berdiam diri dan taat dan hanya dapat menjadi mandiri jikalau menjadi seorang janda, Katharina sudah berpartisipasi secara aktif dalam kehidupan publik berhadapan dengan para bangsawan dan aristokrat, dan dia adalah pasangan yang seimbang dengan suaminya, Mathhew Zell, seorang mantan imam Katholik yang menjadi pendeta Lutheran.

Sebagai seorang istri dari Reformator seperti Schütz Zell, ia membuktikan bahwa dia dapat dan akan mengajar imannya secara intelektual dan menggunakan humor. Dia adalah penulis dari berbagai macam genre teks religius untuk menantang para teolog laki-laki pada masa itu dan konvensi-konvensi budaya pada masa itu dengan berbicara di hadapan publik. Sebagai seorang aktivis, dia mengatur para pengungsi dan menyerukan kepada pemerintah untuk bertanggung jawab terhadap para pengungsi guna kesejahteraan mereka. ${ }^{23}$

Sebagai seorang Katholik yang taat, Katharina muda terlibat aktif dalam aktivitas-aktivitas agama. Dia mendengar ajaran-ajaran Martin Luther yang tersebar di Strasbourg melalui Matthew Zell. Kemungkinan pada akhir tahun 1521 atau awal tahun 1522, dia percaya pemberitaan itu bahwa dia diselamatkan hanya karena iman, dan kasih karunia yang berpusat kepada Kristus semata. Penerimaan dia akan Injil ini tidak serta merta membuat dia 2.

\footnotetext{
${ }^{23}$ Elsie McKee, ed and trans., Church Mother (Chicago: The University Press, 2006),
} 
berpaling dari gereja asalnya. Sebaliknya pengajaran ini memberikannya nafas dalam komitmen dirinya bagi panggilan agamanya. Pengajaran mengenai keimamatan orang percaya memperteguh dia untuk menjadi penjala manusia dengan menceritakan kabar itu kepada semua orang.

Perubahan luar biasa terjadi dalam diri Katharina secara lahiriah dimulai kala dia menikah dengan Matthew Zell, seorang penghotbah terkenal di kota, pada tanggal 3 Desember 1523, yang mana pernikahannya dipimpin oleh Martin Bucer. Katharina juga adalah seorang perempuan terhormat yang pertama menikahi seorang imam. Pengambilan sikap mereka untuk menikah bukanlah hal yang mudah karena pernikahan rohaniwan pada masa itu dilarang dalam hukum kanon, dan dianggap sebagai pelanggaran hukum gereja. Sementara di lain sisi, dalam kelompok Protestan, pernikahan itu adalah suatu kesaksian dari otoritas Kitab Suci melawan ajaran manusia yang menyimpang dari tradisi gereja. Menurut hukum gereja pada masa itu, perempuan yang mau menikah dengan imam harus siap disebut sebagai perempuan yang tidak bermoral. Namun ada banyak perempuan juga yang berani menerima label itu dan karena itu beberapa imam ada yang menikah dengan pembantu rumah tangga. Katharina dikaruniai dua anak, namun disayangkan kedua anaknya meninggal kala bayi dan selanjutnya mereka banyak mengasuh anak-anak yang ada di rumahnya, khususnya anak-anak pengungsi dan anak-anak yatim.

Katharina adalah perempuan terhormat pertama yang menikah dengan imam dan karena itu dia juga banyak menerima tuduhan-tuduhan yang tidak menyenangkan. Katharina dengan berani menulis pembelaannya kepada Bishop di Strasbourg bahwa penikahan rohaniwan itu adalah sesuai dengan Kitab Suci. Pernikahan Matthew dan Katharina juga menjadi pernikahan awal dari kehidupan rumah tangga hamba Tuhan Protestan, dan dengan 
sendirinya Katharina menjadi model dari istri pendeta Protestan juga, selain Katharina von Bora, istri Luther.

Menjalani kehidupan sebagai seorang istri pendeta dilakukan Katharina dengan riang hati dan bahkan kebiasaannya menulis tidak berhenti. Dengan rela dia melayani para pengungsi Protestan yang lari ke Sratrasbourg dan juga menulis surat penghiburan kepada para perempuan yang menderita penganiayaan dari penguasa setempat karena iman Reformasi mereka di Kentzingen sebagai wujud pelayanannya untuk mengajar, mendorong dan menasehati mereka. Pelayanan praktis yang dilakukannya, khususnya memberi pertolongan kepada yang membutuhkan, aktif dalam mengajar, menasehati dan menghibur sesama orang percaya, dan warga negara Strasbourg menjadi hal pokok dalam pelayanan Schütz Zell.

Dalam pernikahan mereka yang harmonis, Zell menjuluki istrinya, Katharina dengan tiga nama, yaitu: "Pasangan yang dinikahi," sebagai ekspresi dari doktrin Protestan mengenai pernikahan; "Ibu dari mereka yang menderita," sebagai perluasan alamiah dari ide mengenai peran perempuan dan ketiga adalah asisten pelayan. ${ }^{24}$ Katharina menyebut dirinya a church mother ("Kirchenmutter"), karena dia yakin bahwa dia dipanggil Allah untuk memelihara gereja dan umat Allah. Dia adalah teolog perempuan pada masa itu. Dia menghadirkan perwakilan dari seorang perempuan Protestan yang dapat bersuara di hadapan publik pada masa itu di tengah situasi di mana banyak perempuan yang masih berdiam diri.

Bergerak keluar dari idealisme perempuan dalam Reformasi yang melakukan pekerjaan rumah tangga, Schütz Zell mengembangkan dirinya ke dalam panggilan teologis yang meluas

\footnotetext{
${ }^{24}$ McKee, ed and trans., Church Mother, 19-20.
} 
dari rumah ke ruang publik dengan terlibat dalam aksi dan kepemimpinan, dengan menafsirkan secara luas apa artinya menjadi pasangan Kristen. Pelayanan publiknya mendapat dukungan kuat dari suaminya. Dia memperluas visi Reformator mengenai peran perempuan, bukan hanya sebagai ibu dan istri dalam keluarga, melainkan juga panggilan keluar untuk berbicara dan bertindak dalam gereja dan masyarakat demi pekabaran Injil dan kesejahteraan sesamanya, dengan banyak bergelut dengan pelayanan pastoral dan pelayanan hospitalitas. ${ }^{25}$

Sebagai seorang teolog awam Protestan, dia banyak menulis berdasarkan Kitab Suci dan menulis juga eksposisi Doa Bapa Kami bagi kaum perempuan dalam situasi mereka pada masa itu. Pasca kematian suaminya pada tahun 1548, Schütz Zell tetap terlibat dalam pelayanan visitasi, mengajar, melayani umat sampai akhir hayatnya. Dia memberikan model bagi perempuan bagaimana sesuatu itu dapat terjadi sebagai akibat dari visi Reformasi. Dia teguh berdiri pada keyakinan dirinya, keterampilan dan kecakapan diri yang dipunyai, panggilannya dan pengaruhnya sebagai seorang perempuan dan seorang kristen.

\section{Argula von Grumbach (1492-1563/68?)}

Argula von Stauff von Grumbach, seorang perempuan bangsawan dari Bavaria Jerman, satu dari perempuan yang sangat visioner yang menulis hal-hal berkaitan dengan Reformasi, sama seperti rekannya Marie Dentière di Jenewa dan Katharina Schütz Zell di Strasbourg. Mereka sadar bahwa sekalipun mereka adalah seorang perempuan, mereka juga memiliki hak istimewa utuk terlibat aktif dalam menyuarakan suara Reformasi dengan menulis risalah teologi. Dia menunjukan suatu tekad besar khususnya bagi seorang perempuan pada zamannya dengan berani menembusi

\footnotetext{
${ }^{25}$ Stjerna, Women and the Reformation, 110.
} 
penghalang yang sudah dibangun berabad-abad demi untuk mengintegrasikan suara Reformasi berhadapan dengan persoalanpersoalan gereja, universitas, dan negara. Keberaniannya membuka jendela kesempatan bagi perempuan selanjutnya untuk dapat berkarya secara leluasa bagi gereja dan masyarakat. Permohonannya bagi toleransi dan dialog menjadi hal yang sangat penting dalam hidup pada hari ini. Kita terpisah dengannya 500 tahun, namun dia seolah-olah hidup sezaman dengan kita pada hari ini, $^{26}$ yang memang miskin dalam gaya hidup toleransi.

Dilahirkan dari keluarga von Stauff dengan delapan saudara, dia memiliki hak istimewa, karena dibesarkan dalam keluarga yang religius dan menghormati adat istiadat dan budaya. Argula menikmati pendidikan privat dan tersedianya banyak buku-buku untuk dibaca. Pada usia sepuluh tahun, ia mendapat hadiah dari ayahnya satu Kitab Suci terjemahan bahasa Jerman tahun 1483 dan dia mulai mempelajarinya dengan tekun. Sebagai seorang pribadi yang senang belajar, Argula memiliki pengetahuan Kitab Suci yang luar biasa. Pada usia lima belas atau enam belas tahun, dia bertemu dengan Johann von Staupitz, bapa rohani Martin Luther, dan di situ dia tertarik dengan Luther. Kala wabah besar menyerang Eropa tahun 1509, Argula kehilangan kedua orang tuanya dan juga pamannya Hieronymous von Stauff, seorang laki-laki terpandang yang menjadi wali menggantikan orang tuanya.

Pada tahun 1516, Argula menikah dengan seorang yang terkenal dan kaya dari Bavaria, Friedrich von Grumbach. Mereka memiliki empat anak, dan di bawah asuhannya dia membesarkan anak-anaknya dalam iman Protestan, meskipun suami dan ayah anak-anaknya tetap seorang Katholik. Suaminya menunjukan ketidak sukaannya dengan Luther hingga kematiannya pada tahun

\footnotetext{
${ }^{26}$ Pether Matheson, Argula von Grumbach (1492-1554/7): A Woman Before Her Time (Eugene, Or: Cascade Books, 2013), xi-xii.
} 
1530. Ketika suaminya pindah ke Dietfurt di Altmühtal sebagai administrator, Argula membantu suaminya menangani persoalan keuangan dan urusan rumah tangga. Sedikit diketahui tentang rumah tangga mereka, namun ada suatu masalah yang timbul dalam rumah tangga mereka, yang nampak dalam tulisan puisi Argula bahwa dia dituduh mengabaikan tugas rumah tangganya oleh suaminya yang memang anti Luther. Kesulitan ini menyebabkan Argula menulis surat kepada sepupunya Adam von Thering untuk meminta saran dan mendoakannya. Meskipun kesulitan besar dia hadapi karena imannya, namun semangatnya tidak pernah pudar untuk mendukung Reformasi. Dia tetap menjalin kontak dengan para Reformator di Wittenberg sepanjang hidupnya, secara khusus dengan Melanchton, Luther dan Spalatin. Risalah-risalahnya selalu menggemakan teologi dasar dari para Reformator, khususnya keimamatan orang percaya. ${ }^{27}$

Keberanian dan simpatinya terhadap gerakan Reformasi Protestan yang sudah menyebar di Jerman tidak membuat dia diam kala pengikut Luther mendapat penganiayaan dan disebut bidah. Kala seorang siswa mendapat serangan karena iman Protestannya, dia membela mahasiswa tersebut dan secara publik menyerang pikiran orang terpelajar di universitas karena sikap mereka. Dia menegaskan bahwa Lutheran itu percaya kebenaran Kitab Suci dan bukan yang lain dan karena itu sangat salah menuduh Lutheran itu bidah. Berkaitan dengan perempuan harus berdiam diri, Argula memberikan respon berdasarkan pembelajaran Kitab Sucinya dan membandingkan teks-teks Kitab Suci dan dia menyimpulkan bahwa dia harus berbicara dengan dasar berpikir bahwa bukan karena bicara itu adalah hak inheren di dalam dirinya, melainkan kesadaran dia akan tanggung jawabnya sebagai seorang Kristen yang sudah dibaptis dalam menyuarakan iman Kristen dan keadilan. Dia berdiri untuk berbicara dan tidak bisa tinggal diam

\footnotetext{
${ }^{27}$ Stjerna, Women and the Reformation, 74.
} 
karena keyakinan di dalam dirinya bahwa sikap itu harus menyatu dalam pemuridan seorang Kristen, meskipun itu beresiko terhadap keluarganya. $^{28}$ Perhatiannya terhadap pemberitaan Injil menyebabkan dia tidak takut mengambil resiko besar dalam diri, dan memang sekalipun dia banyak mengalami penganiayaan, dia tetap dengan berani mengambil jalan mendukung Reformasi, sebagaimana nampak dalam keyakinan dirinya demikian, (dikutip dari Stjerna),

I am prepared to lose everything - even life and limb. May God stand by me! Of myself I can do nothing but sin." Furthermore, she says, "I had intended to keep my writing private; now I see that God wishes to have it made public. That I am now abused for this is a good indication that it is of God. ("To the noble and honourable Adam von Thering, the Count Palatine's Administrator in Neuburg . . . an open letter from Argula von Grumbach, néevon Stauf. ${ }^{29}$

Keteguhannya terhadap prinsip iman Reformasi, Sola Scriptura, yang sudah dipelajarinya, dan diperkaya juga dengan pemahamannya dari Luther, membuat dia menyimpulkan apa itu kebenaran, sebagaimana yang dia tuliskan kepada mereka yang ada di Universitas Ingolstadt, seperti dikutip oleh Stjerna,

I beseech you for the sake of God, and exhort you by God's judgment and righteousness, to tell me in writing which of the articles written by Martin or Melanchthon you consider heretical. In German not a single one seems heretical to me. And the fact is that a great deal has been published in German, and I've read it all ... I have always wanted to find out the truth. Although of late I have not been reading any, for I have been occupied with the Bible, to which all of [Luther's] work is directed anyway-to bring us to read it [Scripture]. My dear lord and father insisted on me reading it, giving me it when I was ten years old. Unfortunately I did not obey him, being seduced by the afore-named clerics,

\footnotetext{
${ }^{28}$ Matheson, Argula von Grumbach (1492-1554/7): A Woman Before Her Time, 47.

${ }^{29}$ Stjerna, Women and the Reformation, 72.
} 
especially the Observants who said that I would be led astray. Ah, but what a joy it is when the spirit of God teaches us and gives us understanding ... I don't intend to bury my talent, if the Lord gives me grace. $^{30}$

Luther menunjukan rasa hormatnya kepada Argula dan menyebut Argula sebagai seorang perempuan saleh, alat khusus dan murid Kristus. Luther mengatakan, sebagaimana tertulis dalam kutipan Stjerna demikian,

The Duke of Bavaria rages above measure, killing, crushing and persecuting the gospel with all his might. That most noble woman, Argula von Stauffer, is there making a valiant fight with great spirit, boldness of speech and knowledge of Christ. She deserves that all pray for Christ's victory in her. She has attacked the University of Ingolstadt for forcing the recantation of a certain youth, Arsacius Seehofer. Her husband, who treats her tyrannically, has been deposed from his prefecture. What he will do you can imagine. She alone, among these monsters, carries on with firm faith, though, she admits, not without inner trembling. She is a singular instrument of Christ. I commend her to you, that Christ through this infirm vessel may confound the mighty and those who glory in their strength. ${ }^{31}$

Argula hidup dalam suatu masa di mana kerinduan akan emansipasi bagi perempuan itu dialami. Dia membawa semangat seorang yang meyakini Injil sedemikian kokoh dan berbicara sebagai seorang teolog awam perempuan pada eranya, sebagai seorang Kristen dan sebagai seorang guru Kitab Suci, pembela hakhak agama sesamanya, dan menawarkan lensa Kitab Suci yang membawa angin perbuahan secara sosial dan teologis.

\section{Marie Dentière (1495-1561)}

\footnotetext{
${ }^{30}$ Stjerna, Women and the Reformation., 75.

${ }^{31}$ Ibid., 79.
} 
Marie adalah nama perempuan satu-satunya yang tertulis dalam tembok Reformasi di Jenewa. Namanya masuk dalam jajaran Reformator di Jenewa di mana Calvin melayani pada abad ke-16. Marie adalah satu dari banyak perempuan pada masa itu yang membawa banyak terobosan dalam Reformasi di Jenewa, khususnya di kalangan perempuan. Dia dilahirkan dari kalangan keluarga bangsawan dan menjadi biarawati di biara Agustinian, Tournai-Belgia. Dia meninggalkan biaranya setelah mendengar banyak ide-ide mengenai Reformasi dan selanjutnya dia pergi ke Strasbourg, di mana di sana dia menikah dengan Simon Robert, mantan imam.

Aktivitasnya sangat banyak dan dia memulai sekolah bagi para gadis bersama dengan suaminya. Dia mendorong para biarawati untuk bergabung dengan Reformasi dan menikah serta menulis sejarah pembebasan Jenewa dari Katholik dan bahkan dia berkorespondensi dengan Marguerite de Navarre. Pada tahun 1533, Robert, suami Marie, meninggal dunia dan tahun 1535 dia menikah lagi dengan Antoine Froment dan pasangan ini kemudian menetap di Jenewa, di mana Froment melayani.

Marie adalah pembicara yang ulung berkaitan dengan isu-isu yang diperdebatkan oleh para Reformator dan Gereja Katholik saat itu, khususnya penolakan terhadap selibasi, mendukung pendidikan bagi perempuan dan keterlibatan perempuan dalam peran mereka di gereja. Dalam hal ini dia memainkan peran penting sebagai seorang perempuan yang notabene guru dari doktrin gereja dan moral. Dia adalah pendukung dari Gerakan Reformasi yang berbahasa Perancis dan pendukung Farrel dan Calvin dalam misi mereka di 
wilayah Swiss yang berbahasa Perancis. Marie jugalah yang protes keras kala Farrel dan Calvin ditarik keluar dari Jenewa. ${ }^{32}$

Meskipun demikian, John Calvin pernah menegurnya karena pandangannya sangat vokal mengenai peran perempuan dalam gereja dan karena itu dia mengkritik para pelayan di Jenewa masa itu termasuk Calvin, berkaitan dengan peran perempuan. Sekalipun Calvin tidak setuju dengan Marie mengenai posisi perempuan, namun pada akhirnya dia juga menulis kata pembuka dari salah satu khotbah Calvin mengenai kesopanan yang terambil dari surat 1 Timotius, yang diterbitkan pada tahun 1561. Usia yang bertambah menjadikannya berhikmat dalam memberikan respon terhadap isuisu yang menimbulkan perdebatan, atau bisa jadi rekonsiliasi Marie dan Calvin karena alasan Reformasi atau yang lain. Sejarah tidak mencatat hal ini. Namun yang jelas, pada akhir menjelang hidup mereka didapati adanya rekonsiliasi di antara mereka.

Tulisannya Very Useful Epistles (1539) menjadi pernyataan teologinya yang ditulis dalam bahasa Perancis. Dalam bagian ini dia bergerak dari keimamatan orang percaya dengan mengajukan pertanyaan dasar yang menantang gereja berpikir mengenai peran perempuan dalam gereja, demikian,

Do we have two Gospels, one for men and another for women? One for the wise and another for the fools? Are we not one in our Lord? In whose name are we baptized? By Paul or by Apollo, by the pope or by Luther? Is it not in the name of Christ? [d1v] He is certainly not divided. There is no distinction between the Jew and the Greek; before God, no person is an exception. We are all one in Jesus Christ. There is no male and female, nor servant nor free man. $^{33}$

\footnotetext{
${ }^{32}$ Mary B. McKinley, ed., "Volume Editor's Introduction," Marie Dentière: Epistle to Marguerite de Navarre and Preface to a Sermon by John Calvin (Chicago: University Press, 2004), 1-2.

${ }^{33}$ McKinley, ed , Marie Dentière: Epistle to Marguerite de Navarre, 79.
} 
Sikap dan kritik dia terhadap para pelayan yang notabene laki-laki pada masa itu memang menimbulkan reaksi keras dari Calvin. Namun pada akhirnya sejarah juga mencatat bahwa Calvin memintanya menulis kata-kata pembukaan dalam khotbahnya yang akan dipublikasikan. Terlepas dari keberdiaman sejarah mengenai apa yang terjadi sesungguhnya mengenai peran perempuan di Jenewa, Marie Dentière melibatkan dirinya dalam perjuangan Reformasi di Jenewa.

\section{Olympia Fulvia Morata (1526-1555)}

Terlepas dari hidupnya yang sangat singkat, Olympia Morata mengukir sejarah dalam Reformasi sebagai seorang perempuan yang berkarya di Italia dan kemudian pindah ke Jerman. Namanya muncul dalam panggung sejarah pada usia empat belas tahun dan seorang Humanis Italia, Lilio Gregorio Giraldi menulis bahwa dia adalah seorang gadis yang melampaui sesamanya pada masa itu, karena dia bukan hanya belajar bahasanya sendiri, melainkan juga mempelajari bahasa Latin dan Yunani, dan karena itu menjadikan dia sangat menonjol pada masa itu. ${ }^{34}$ Ayahnya, Fulvio Pellegrino Morato, dengan nama yang dilatinkan Fulvius Peregrinus Moratus, adalah seorang yang juga mendapatkan ide-ide Reformasi yang menyebar di Italia. Moratus adalah seorang guru literatur klasik, yang banyak memberikan pengaruh kepada Morata muda tentang ide-ide Reformasi. Dia juga memperkenalkan kepada siswanya tulisan-tulisan dari John calvin dan Reformator lainnya.

Di tengah masa konflik yang sulit, Morata muda tampil di depan umum di Akademi Privat dari Ratu Ferrara, yaitu di villa Renêe de France dengan memberikan kuliah mengenai tulisan

\footnotetext{
${ }^{34}$ Simonetta Carr, Olympia Morata: Champion of the Reformation, diakses dari http://www.reformationitaly.org/2011/01/olympia-morata-champion-of-the-reformation, tanggal 20 Juli 2017.
} 
Cicero, Stoic Paradoxes sekitar bulan April atau Oktober $1541 .^{35}$ Pasca memberikan kuliah singkat ini, namanya menjadi terkenal dan karena itu raja dan ratu kemudian mengatur jadwal baginya untuk memberikan kuliah publik selanjutnya. Pujian juga berdatangan bagi ayah dari Morata, dan justru membingungkan bagi para pemimpin gereja masa itu karena tulisan dari Morata menghembuskan pendidikan teologi Reformasinya. Meskipun dapat dikatakan bahwa dia tidak pernah menyebutkan dirinya Reformed atau Lutheran, karena memang dia sangat akrab dengan tulisan Luther dan Calvin dan menghindari bersikap dikotomis di antara keduanya. Dia memang merindukan bukan soal dogma yang didefinisikan manusia, melainkan apa yang menjadi percakapan Injil, itu yang ditekankannya, khususnya dalan diskusi dia mengenai natur Ekaristi dan doktrin predestinasi. Sikap dia yang cinta damai ini lebih mirip dengan sikap Melanchton dalam Reformasi. $^{36}$

Pada tahun 1550, Olympia Morata menikah dengan seorang Reformed Jerman, Andreas Grunthler, yang terlatih dalam soal obat-obatan, namun di sisi yang lain ia juga tertarik dengan literatur klasik. Setelah menikah hidup mereka tidaklah menjadi mudah karena mereka justru mendapat banyak persekusi. Kala mereka kembali ke Jerman, suaminya berharap mendapatkan posisi mengajar dan memang mereka berdua mengajar pada akhirnya di Unversitas Heidelberg, pada masa pemerintahan Frederick II.

Pada masa sekembalinya dia ke Heidelberg, itu adalah masamasa akhirnya karena setahun kemudian dia menderita sakit. Terlepas dari sakit yang dialaminya, yaitu tuberkolosis, dia memohon salinan tafsiran Ratapan yang ditulis Calvin dan yang baru diterbitkan. Dia juga mempelajari dengan serius tafsiran

\footnotetext{
${ }^{35}$ Olympia Morata, The Complere Writings of an Italian Heretic, edited and trans., by Holt N. Parker, (Chicago: University of Chicago, 2003), 2.

${ }^{36}$ Morata, The Complere Writings of an Italian Heretic, 49.
} 
Yesaya dari Calvin. Dia menulis banyak surat dalam korespondensi dia untuk menyebarkan ide-ide Reformasi khususnya di negara asalnya Italia. Kesenangannya dalam belajar dan menyebarkan berita Reformasi melalui surat menyurat tidak pupus sekalipun fisik melemah. Akhirnya pada tanggal 26 Oktober 1555, Olympia wafat dan Theodore Beza menuliskan eulogia baginya. Hidupnya singkat, namun penuh dengan makna dan setia dalam kerajaan Allah, sesuai dengan apa yang menjadi kerinduannya, "There is no part of the world so distant that we would not be glad to live in it, if we could but serve God there with full liberty of conscience."Grunthler menyusun suatu ratapan dirinya bagi istrinya dalam suatu komposisi "Quemadmodum desiderat cervus ad fontes aquarum" (As the hart panteth after the water brooks; Ps. 42:1). Namun dua bulan kemudian Grunthler dan saudara laki-laki Olympia meninggal dunia juga karena wabah yang menyerang. Mereka dimakamkan di Gereja Santo Petrus di Heidelberg.

Olympia Morata adalah seorang yang brilian dan banyak menulis ungkapan-ungkapan dalam bahasa Latin. Surat-suratnya menggambarkan masa-masanya yang sulit, dan dari ekspresi ini kita dapat juga menemukan catatan sejarah tentang kesulitan yang dihadapi oleh Gerakan Protestan mula-mula. Surat-surat dan dokumen teologis yang ditulisnya bukan hanya menyatakan keikutsertaan dia dalam perjuangan Reformasi, namun juga menunjukkan keberanian seorang perempuan dalam berkhotbah di tengah situasi di mana perempuan dilarang mengajar laki-laki. Morata berbicara dari posisi sebagai seorang yang ahli dalam ilmu dan juga menunjukkan kesalehan hidupnya. Karena itu, Morata menjadi sumber inspirasi bagi banyak perempuan yang terpelajar pada masanya, yang mengikutinya, diantaranya, Catharine des Roches (1550-1587), Elizabeth Jane Weston (1582-1612), 
Bathsua Makin (1600-1674?), Anna Maria van Schurman (16071678), dan Mary Robinson (1758-1800). ${ }^{37}$

\section{Marguerite de Navarre (1492-1549)}

Marguerite de Navarre sejatinya adalah seorang perempuan Renaisans. Dia dilahirkan pada tahun yang sama saat Columbus menemukan benua Amerika. Marguerite adalah kakak dari raja Francis I, yang kepadanya Calvin mendedikasikan Institutio-nya. Marguerite adalah putri dari Alençon dan Berry dan Ratu dari Navarre, yang dilahirkan di Angoulême bagi Louise de Savoie dan Charles d'Angoulême. Pada tahun 1509, Marguerite menikah dengan Charles duc Alençon, namun pernikahan ini kurang bahagia dan karena itu dia siap menolong saudaranya, Francis I, kala dibutuhkan sebagai tuan rumah bagi tamu-tamu negara, sehubungan dengan istri Francis I, Claude, tidak mampu melayani tamu-tamu negara yang berasal dari seluruh Eropa. ${ }^{38}$

Pada masanya, Marguerite adalah perempuan yang sangat terdidik di Perancis, dan sekaligus sebagai seorang diplomat ulung, seorang penasehat dekat raja dan model dari perempuan berteologi. Ketika Francis I dikalahkan dan dibawa sebagai tawanan ke Spanyol, dan suaminya juga yang wafat dalam pertempuran di Pavia, Marguerite datang ke Spanyol dan bernegosiasi dengan kaisar Charles V, seorang penganut Katholik Roma. Segera setelah Francis dibebaskan, Marguerite menikah lagi dengan Henri d'Albret, Raja Navarre dan mereka dikaruniai seorang putri pada bulan Januari 1527 serta putrinya diberi nama Jeanne d'Albret.

\footnotetext{
${ }^{37}$ Holt Parker, "Morata Fulvia Olympia (1526/1527-1555)," Encyclopedia of Women in the Renaissance: Italy, French and England, Diana Robin, Anne R. Larsen, and Carole Levin, eds, (Oxford: ABC CLIO, 2007), 269-271.

${ }^{38}$ Carol Thysell, The Pleasure of Discerment: Marguerite De Navarre as a Theologian, 7.
} 
Anak laki-laki mereka lahir pada bulan Juli tahun 1530, namun meninggal dunia pada masa raya natal. ${ }^{39}$

Satu dari karya puisi Marguerite, Dialogue in the Form of a Nocturnal Vision, merefleksikan pengalaman dan menggemakan nasehat dari Guillaume Briçonnet, seorang pemimpin kelompok Evangelikal, yang disebut kelompok Meaux, yang mencakup Jacques Lefèvre d'Etaples, Gérard Roussel, Guillaume Farel, Jodocus Clichtove, François Vatable, and Martial Mazurier. Kelompok ini menggabungkan ide humanisme dengan kembali mempelajari Alkitab, khususnya surat-surat Paulus, sebagai sumber utama doktrin kristen. Pada tahun 1520-an, kelompok ini disebut sebagai kelompok bidah oleh para teolog Sorbonne, yang notabene Katholik. Para teolog Sorbonne ini juga melarang penyebaran ide Reformasi dari Luther di Perancis. Marguerite berusaha menolong para Reformator ini dari tekanan mereka yang membenci ide-ide Reformasi.

Marguerite sendiri pada tahun-tahun tersebut juga menyebarkan ide dan tulisan Reformasi, khususnya dia menulis tafsiran doa Bapa Kami, dengan mengambil contoh dari Luther, dan pada akhirnya ia juga mendapat kritikan tajam dari para Teolog Sorbonne karena tulisan-tulisannya yang cenderung bersifat evangelikal, dan bahkan dia sebenarnya dapat dihukum dengan cara dibakar seandainya dia bukan saudara perempuan raja. Korespondensi Marguerite sangat luas dan dia juga banyak bersurat dengan Reformator Strasbourg, Wolfgang Capito, satu dari pengikut Luther, yang memberikannya salinan dari karya-karya Reformator Jerman.

\footnotetext{
${ }^{39}$ Mary McKinley, "Marguerite de Navarre (Marguerite d'Angoulême, Margaret of Navarre; 1492-1549)," Encyclopedia of Women in the Renaissance: Italy, French and England Encyclopedia of Women in the Renaissance: Itay, French and England, 229.
} 
Marguerite juga berkorespondensi dengan John Calvin, dan Calvin meneruskan tali silaturahmi ini kepada putri dari Marguerite, Jeanne d'Albret pasca kematian Marguerite. Korespondensi ini sangat penting dalam Reformasi, karena Calvin khususnya sadar benar bahwa perempuan-perempuan bangsawan ini memiliki pengaruh yang kuat dalam penyebaran Reformasi ini. Karena itu, Calvin juga membangun tali persahabatan dengan Renee de France, putri dari Ferrara.

Sekalipun hubungan ini sangat akrab, namun Calvin juga tidak ragu mengkritik Marguerite secara tidak langsung yang sudah menjadi pendukung dari kelompok "Spiritual Libertines." Di sisi lain, Marguerite juga memberikan respon balik secara tidak langsung melalui karyanya Comedy of the Mount of Marsan (1546). Pada akhir-akhir hidupnya, Marguerite banyak menulis respon terhadap isu-isu teologis yang sedang hangat pada masa itu. Karyanya yang bersifat teologis sebagai respon terhadap isu yang ditulis oleh Calvin, "Melawan Kebebasan Rohani," Marguerite menulis Heptameron, yang diterbitkan pasca kematiannya. Suatu koleksi tulisan dari 72 kisah yang dibentuk oleh kisah dari sekelompok peziarah yang dikejutkan oleh banjir di pegunungan Cauteret, Perancis.

Kontribusinya dalam Reformasi sangat penting yaitu dengan memberikan sponsor bagi para teolog Reformasi dan karya mereka, memberikan perlindungan kepada para pengungsi Protestan pada masa itu dan bahkan dia pernah memberikan tumpangan kepada John Calvin yang lari dari Paris sebelum pergi ke Jenewa. Dia memang tetap sebagai seorang Katholik, dan bukan Protestan. Seperti para Reformator dari Meaux, dia tidak berpisah dengan gereja asalnya, namun berupaya keras mengarahkan gereja kembali kepada pengajaran yang benar. Seperti para Reformator Meaux, dia menantang para imam yang tidak membagikan tafsiran dari teks, 
dan karena itu dia menginginkan Kitab Suci dapat dibaca oleh semua umat.

Dia mempraktikkan apa yang para Reformator khotbahkan. Dia bekerja dengan rajin untuk memperbaiki keadaan di rumah sakit dan menciptakan ruang aman bagi anak-anak yatim piatu. Dia juga adalah penyumbang setia untuk menegakkan kehidupan beragama yang benar, menurunkan para pemimpin agama yang tidak kompeten dan menjadikan aturan biara itu menjadi lebih intelektual dan aplikatif. Putrinya, Jeanne d'Albret kemudian menjadi ibu dari Henri IV, yang pada tahun 1598 mengeluarkan Keputusan Nantes, yang melindungi kelompok minoritas Protestan Perancis selama bertahun-tahun sampai dibatalkannya keputusan tersebut oleh Louis XIV pada tahun $1685 .^{40}$

Marguerite memerankan peran yang beraneka ragam dalam periode Reformasi, dari mereformasi para biarawan, tuan rumah di istana, dan menjadi diplomat. Dia hidup pada masa yang tidak lazim dalam perkembangan Protestan di Perancis, namun dia juga tidak meninggalkan iman Katholiknya, dengan membangun relasi harmonis di antara Vatikan dan Jenewa. Peran penting yang dibangun di tengah konflik, yang menjadikannya sebagai figur penting dalam Reformasi dan pelindung bagi para Reformator.

\section{Renée de France (Renata di Francia) (1510-1575)}

Dilahirkan di Perancis dalam keluarga Louis XII dan Anne of Brittany, saudara ipar dari Raja Francis I. Renée menikah dengan Ercole Il d'Este, Pangeran dari Ferrara pada tahun 1528, dan menjadi Renata di Francia. Tiba di Ferrara dengan segala hak istimewanya sebagai seorang putri raja Perancis, Renata membuat

\footnotetext{
${ }^{40}$ Patricia F. Cholakian and Rouben C. Cholakian, Marguerite de Navarre: Mother of the Renaissance, (New York: Colombia University Press, 2006), 5.
} 
Istana Este menjadi tujuan bagi para seniman dan filsuf serta rumah bagi para pemikir Reformasi pada tahun 1530-an dan 1540-an. Terdidik di bawah asuhan kakak sepupunya dan juga sekaligus mentornya, Marguerite de Navarre, Renata memberikan perlindungan kepada Calvin pada tahun 1536. Di bawah pengawasan sang putri, karya utama Calvin, The Institutes of the Christian Religion, disebarkan di istana Este dalam dua edisi bahasa Latin, $(1536,1539)$ dan edisi bahasa Perancis, $1541 .^{41}$ Renata memberikan tumpangan juga kepada mereka yang disebut bidah oleh gereja pada masa itu, dan di antara mereka yang diberi tumpangan adalah Secondo Curione dan Olympia Morata.

Sikap Renata yang pro Protestan memaksa Pangeran Ercole, seorang Katholik yang taat, untuk membuat Renata meninggalkan kepercayaan Protestannya. Meskipun demikian, Renata tetap bertahan dan tetap membangun relasi dengan Jenewa, khususnya dengan John Calvin melalui surat menyurat. Kala Ercole wafat pada tahun 1559, Renata kembali ke tempat kelahirannya di Montargis hingga akhir hidupnya sebagai seorang Protestan. Meskipun dia tidak pernah membuat pengakuan publik tentang iman Protestannya, namun cukup jelas untuk dikatakan bahwa dia adalah pengikut Protestan dari perbuatannya. Satu hal saja yang jelas dia ungkapkan secara pribadi kala dia mengucapkan kata-kata selamat tinggal kepada anak-anaknya, bahwa dia adalah pengikut dari Calvin. $^{42}$

Di Montargis, dia mengalami banyak kesulitan sebagai seorang Protestan karena anak menantunya, Francis of Guise merampas kastilnya di Montagis selama perang agama di Perancis. Masa-masa yang sulit dijalani olehnya di Montagis, kala putrinya, Anne, yang dibesarkan dalam iman Protestan, berusaha membalas

\footnotetext{
${ }^{41}$ Diana Robin, "Renata di Francia (Renée de France, 1510-1574)," Encyclopedia of Women in the Renaissance: Italy, French and England, 322.

${ }^{42}$ Stjerna, Women and the Reformation, 195.
} 
dendam atas kematian suaminya, yang notabene Katholik dan menjadi pemimpin dalam pembalasan dendam akibat perang agama ini. Renata dituduh terlibat dalam pembunuhan ini dan dalam masa sedih yang dalam, Calvin di atas ranjang menjelang kematiannya, menghiburnya, dengan mengingatkan dia untuk teguh dalam perjuangan, sebagaimana nasehat ini dituangkan dalam tulisan Stjerna demikian, "I am confident that you will do your whole duty according to your zeal for having God served and honored more" (April 4, 1564...). ${ }^{43}$

Tahun-tahun kehidupannya yang sangat penting bagi perkembangan Protestan di Perancis menjadi bagian penting dalam catatan sejarah, di mana perempuan ini tetap konsisten dengan imannya dan dengan apa yang ada pada dirinya berjuang untuk membela keyakinannya agar dapat beribadah sesuai dengan pilihan nurani yang diambilnya.

\section{Anne Askew (1521-1546)}

Anne Askew adalah seorang teolog dan martir Protestan dari Inggris. Anne Askew dilahirkan di Kelsey Selatan, Lincolnshire pada tahun 1521. Dia adalah anak kelima dari enam bersaudara bagi William Askew dan Elizabeth Wrottesley Askew. Karena saudara perempuannya, Martha, meninggal dunia sekitar tahun 1540, maka ayahnya memaksanya untuk menikah dengan tunangan kakaknya, Thomas Kyme. Pernikahan ini sangat tidak bahagia bagi Anne Askew. Dengan sikap otoriternya, akhirnya Kyme memaksa Anne keluar dari rumahnya, karena kepercayaan Anne kepada ideide Protestan. ${ }^{44}$

\footnotetext{
${ }^{43}$ Stjerna, Women and the Reformation, 191-192.

${ }^{44}$ Randall Martin, ed., Women Writer in Renaissance England: An Annotated Anthology, 2nd Edition, (London: Pearson, 2010), 58.
} 
Tulisan Askew, Examination, menunjukkan bahwa Anne Askew adalah seorang yang terpelajar dengan pengetahuannya yang baik tentang Kitab Suci dan retorika. Tulisan ini juga merupakan respon perempuan yang mempertanyakan idealisme masyarakatnya tentang keperempuanan. Bukannya menampilkan dirinya sebagai perempuan yang diam dan tidak berdaya, Askew justru berbicara di depan publik, karena itu dia dijuluki sebagai "gospeller," dan menulis kisahnya serta berargumentasi dengan para inkuisitor pada masa itu untuk menegur mereka karena kesalahan-kesalahan mereka. Askew banyak mendapat dukungan dari Ratu Catherine Parr dan anggota keluarganya yang sangat bersimpati dengan Protestantisme.

Dalam arena politik, para musuh Potestan seperti Stephen Gardiner, Bishop Winchester, Thomas Wriothesley dan Edmund Bonner, Bishop London, sudah mengamati dengan seksama gerakgerik dari ratu Catherine yang mendukung Kelompok Protestan. Mereka berusaha keras untuk mematahkan usaha dan gerakan Protestan, namun belum berhasil karena memang dilihat bahwa sahabat Raja Henry VIII, Uskup Agung Thomas Cranmer, adalah notabene pendukung dari Reformasi. Para musuh ini berusaha mencari jalan dan menemukan cara mereka untuk mematahkan gerakan ini melalui Askew yang adalah sahabat dari Catherine Parr.

Anne Askew ditangkap dan diinterogasi pada bulan Maret 1545 berkaitan dengan penolakannya terhadap ajaran transubstansiasi. Penolakannya yang kokoh terhadap ajaran transubstansiasi ini berujung kepada hukuman bahwa dianggap sebagai bidah, dan karena itu dijatuhi hukuman mati dengan cara dibakar. Para musuhnya berusaha membujuk dia sebelum dibakar seandainya dia mau melepaskan iman Protestannya. Namun Askew dengan kokoh tetap berpegang kepada keyakinan Protestannya, dan tidak dapat melepaskan atau mengingkarinya. Karena kekokohan 
sikapnya, maka akhirnya dia mati dengan cara dibakar. Sikapnya tersebut juga menjadi contoh bagi para martir yang lain yang juga akan dibakar bersama dengannya, untuk tetap berpegang kepada keyakinan Protestan. ${ }^{45}$

Dalam doanya bagi para musuh Protestan, yang menganiayanya sebelum dia dibakar, dia berseru, demikian,

"Lord, I heartily desire of thee that thou wilt of thy most merciful goodness forgive them that violence which they do, and have done, unto me. Open also thou their blind hearts, that they may hereafter do that thing in thy sight, which is only acceptable before thee, and to set forth thy verity aright, without all vain fantasies of sinful men. So be it, O Lord, so be it!"

Dengan menyebutkan beberapa perempuan di atas tidak berarti hanya mereka saja yang tercatat dalam peran penting Reformasi. Masih banyak para perempuan yang tercatat dalam perjuangan Reformasi dengan kontribusi masing-masing yang mereka berikan. Namun cukuplah bagi para pembaca mengetahui beberapa representasi dari perempuan-perempuan di atas dan menemukan peran penting yang mereka berikan dalam Reformasi, sebagai istri, dan sebagai pejuang Reformasi.

\section{SIMPULAN}

Reformasi Protestan sudah membawa angin segar dalam membuka babak baru peran perempuan, yang sebelumnya hidup lajang dan membiara sangat dimuliakan dibandingkan hidup

${ }^{45}$ John N. King, ed., Foxe's Book of Martyrs: Select Narratives, (Oxford: University Press, 2009), 34.

${ }^{46}$ Christina Langella, Women of the Reformation: Anne Askew; Gospelling In The Fire by Diane Bucknell, diakses dari http://christinalangella.com/womenofthereformation/women-of-the-reformation-anneaskew-gospelling-in-the-fire-by-diane-bucknell, tanggal 22 Juli 2017. 
menikah dan berkeluarga. Reformasi menegaskan bahwa hidup menikah adalah panggilan juga bagi orang percaya. Meskipun nampak sikap dari para Reformator terhadap peran perempuan yang dikembalikan kepada rumah dan keluarga sebagai tempat mereka, namun tidak berarti bahwa peran perempuan dibatasi pada ruang demikian. Situasi yang kompleks pada abad ke-16 menyebabkan tidak mudah bagi perempuan untuk melakukan peran mereka di luar rumah. Namun itu tidak berarti mereka tidak melakukan peran besar mereka. Perubahan besar berkaitan dengan perempuan lebih terbuka luas pada abad ke-18 dengan merekahnya era Pencerahan di Eropa. Perempuan yang dahulunya cenderung diposisikan sangat subordinat dengan laki-laki, selanjutnya ditempatkan sebagai mitra dalam berkarya. ${ }^{47}$

Penulis berasumsi bahwa sikap para Reformator sangat progresif berhadapan dengan situasi abad ke-16 yang mengalami proses perubahan agama yang dikaitkan dengan berbagai macam kekuatan politik, intelektual, sosial, ekonomi, di mana semuanya sangat kompleks, ambigu dan bahkan dapat menjadi kontradiksi. Perubahan ini mempengaruhi kehidupan dalam berbagai macam cara sehingga melampaui kriteria tunggal dan sederhana untuk menilai apa yang terjadi pada masa itu. ${ }^{48}$ Karena itu, jikalau ada penilaian bahwa sikap para Reformator masih sedikit ambigu mengenai sikap mereka terhadap perempuan, maka cukup penting beralasan di sini bahwa tidak semudah untuk mengatakan bahwa memang terjadi sikap demikian. Sekalipun para Reformator mengharapkan perempuan tunduk pada hirarki ciptaan, namun itu tidak berarti menjadikan perempuan terkurung dalam dunia sempit keluarga dan mengabaikan dunia Allah yang luas untuk mereka dapat berkarya dan melayani.

\footnotetext{
${ }^{47}$ Lihat diskusi panjang mengenai peran perempuan pada abad ke-18 dalam tulisan Jennine Hurl-Eamon, Women's Role in Eighteen Century Europe, (Santa Barbara: Greenwood, 2010), xi-xvii.

${ }^{48}$ Thysell, The Pleasure of Discerment, 5.
} 
Mengembalikan pernikahan sebagai bagian penting dari panggilan Allah, bukan hanya ditujukan bagi para perempuan, namun juga kepada laki-laki pada masa itu. Di tengah masa transisi yang kompleks dari kehidupan membiara, maka sangat penting menetapkan suatu tujuan awal, yang dimulai dari rumah, sebagaimana itu yang sangat ditekankan oleh Reformator, khususnya Martin Luther bahwa rumah tangga itu dikelola laksana kerajaan di bumi di mana orang tua melatih anak-anak dalam perintah Allah dan karena itu, keluarga adalah komponen penting dari kehidupan sosial dalam setiap budaya. Orang tua membesarkan anak-anak dengan tujuan agar mereka dapat melayani Allah. ${ }^{49}$ John Calvin dan Zwingli juga melihat hal yang sama seperti Luther, bahwa rumah itu memiliki peran besar di dalamnya di mana orang tua memiliki tanggung jawab untuk membimbing anak-anak kepada kesalehan dengan tanggung jawab bersama dari orang tua, baik itu ayah dan ibu, khususnya peran besar dari ayah. ${ }^{50}$

Di sisi lain, sikap teologis mereka, khususnya John Calvin, mendorong perempuan untuk bersikap lebih puas dan mawas diri dalam hirarki ciptaan sambil mendorong mereka untuk menerima realita ini dalam penantian mereka akan kedatangan kerajaan Allah yang sejati. Menariknya sekalipun sikap itu demikian, namun Calvin bukanlah orang yang bersikap kaku karena dalam meresponi peran perempuan dalam Reformasi, dia justru banyak memberikan dukungan kepada mereka dalam perjuangan, khususnya kepada Marguerite de Navarre dan putrinya, Jeanne d'Albret. Di tengah masa di mana perempuan tidak mudah untuk menjalankan peran mereka dalam gereja dan sebagai pengajar juga kepada para laki-

\footnotetext{
${ }^{49}$ C. Jeffrey Robinson Sr, "The Home is an Earthly Kingdom," Trained in the Fear of God, ed. By Randy Stinson \& Timothy Paul Jones, (Grand Rapids: Kregel, 2011), 117.

${ }^{50}$ Ibid., 118.
} 
laki, para Reformator tidak mematikan karunia mereka, melainkan justru mendukung mereka, dan bahkan menguatkan mereka berhadapan dengan kesulitan pada masanya. Luther juga memuji Argula von Grumbach dalam perjuangannya dalam Reformasi dan bahkan memujinya sebagai seorang murid Kristus.

Sikap keras Calvin ditujukan kepada Marie Dentière, karena sikapnya yang agresif dan ofensif dalam perjuangannya. Namun pada akhirnya kritikan keras ini bukan berarti menghambat karunia dari perempuan ini dalam beraktualisasi diri dalam perjuangan Reformasi. Calvin juga pada akhirnya meminta dia menuliskan kalimat pembukaan dalam salah satu bagian khotbahnya dari 1 Timotiusnya. Calvin juga pernah menegur Marguerite de Navarre secara tidak langsung dalam tulisannya, bukan karena menghambat perannya dalam Reformasi, namun justru karena sikap teologis Marguerite terhadap "Spiritual Libertines." Jadi, para Reformator sangat membuka ruang bagi perempuan dalam kontribusi mereka bagi kerajaan Allah dengan dorongan tanpa melupakan hakekat sejati mereka dalam panggilan sebagai ayah dan ibu dalam keluarga, khususnya bagi perempuan.

Hal yang menarik bagi para perempuan dalam kontribusi mereka sebagaimana disebutkan di atas adalah bahwa mereka itu adalah seorang istri, baik dari seorang pendeta maupun istri dari seorang bangsawan negara pada masa itu. Dalam peran mereka yang tidak mudah, mereka menempatkan diri mereka dengan sadar bahwa mereka adalah partner bagi suami dan mendukung pelayanan suami mereka, khususnya mereka yang adalah istri seorang pendeta atau pelayan jemaat. Para perempuan Reformasi ini memainkan peran mereka dengan sangat atraktif dan adaptif sesuai dengan kemampuan dan karunia yang ada pada mereka, entah melalui tulisan atau percakapan publik, tanpa melupakan hakekat diri mereka. Memang ada di antara mereka yang 
mengalami kesulitan dalam pernikahan dan rumah tangga mereka karena rangkulan mereka terhadap ide-ide Reformasi, yang notabene berbeda dengan para suami mereka, khususnya perempuan-perempuan dari kalangan bangsawan, namun mereka tetap sabar melewati tanggung jawab mereka dan dengan berani masuk dalam perjuangan Reformasi. Mereka membesarkan anakanak mereka dalam semangat Protestan.

Pokok penting di sini adalah bahwa peran perempuan dalam Reformasi tidak dapat diabaikan dan mereka memberikan kontribusi mereka dengan sangat persuasif, gigih dan penuh keberanian, sekalipun resiko besar terbentang di depan mereka. Mereka dengan rela mengambil resiko ini demi pembaharuan kehidupan dalam perarakan iman gereja sesuai dengan berita Injil. Mereka sudah berkarya dalam waktu dan di tempat di mana mereka ada dan sekarang para perempuan dalam gereja hari ini meneruskan tanggung jawab ini dengan setia dengan menyadari hakekat diri dan karunia yang Allah sudah berikan kepada mereka. Menutup artikel ini tidak dapat diabaikan apa yang dikatakan Luther di bawah ini sebagaimana dikutip oleh Christina Langella demikian,

"The home, cities, economic life, and government would virtually disappear. Men can't do without women. Even if it were possible for men to beget children and bear children, they still couldn't do without women." - Martin Luther. ${ }^{51}$

${ }^{51}$ Christina Langella, The Women of the Reformation Series at Heavenly Springs, diakses dari http://christinalangella.com/women-of-the-reformation-starting-october-31st/, tanggal 22 Juli 2017. 


\section{DAFTAR RUJUKAN}

\section{PUSTAKA}

Capern, Amanda. The Historical Study of Women: England 1500 1700.(Basingstoke, UK: Palgrave Macmillan, 2010.

Chappell, Julie A. and Kaley A, Kramer, ed. Women during the English Reformations: Renegotiating Gender and Religious Identity. New York: Palgrave Macmillan, 2014.

Cholakian, Patricia F. and Rouben C. Cholakian. Marguerite de Navarre: Mother of the Renaissance. New York: Colombia University Press, 2006.

DeRusha, Michelle, Katharina and Martin Luther: The Radical Marriage of a Runaway Nun and a Renegade Monk. Grand Rapids: Baker Book Ho, 2017.

Douglass, Jane Dempsey. Women Freedom and Calvin. Philadelphia: Westminster Press, 1985.

King, John N. ed. Foxe's Book of Martyrs: Select Narratives. Oxford: University Press, 2009.

Martin, Randall. Ed. Women Writer in Renaissance England: An Annotated Anthology, 2nd Edition. London: Pearson, 2010.

Matheson, Pether. Argula von Grumbach (1492-1554/7): A Woman Before Her Time. Eugene, Or: Cascade Books, 2013.

McKee, Elsie, ed and trans. Church Mother. Chicago: The University Press, 2006. 
McKinley, Mary B. Ed. "Volume Editor's Introduction," Marie Dentière: Epistle to Marguerite de Navarre and Preface to a Sermon by John Calvin. Chicago: University Press, 2004.

McKinley, Mary. "Marguerite de Navarre (Marguerite d'Angoulême, Margaret of Navarre; 1492-1549)," Encyclopedia of Women in the Renaissance: Italy, French and England Encyclopedia of Women in the Renaissance: Itay, French and England. Oxford: ABC CLIO, 2007.

Moore, Rebecca. Women in Christian Tradition. New York: New York University Press, 2015.

Morata, Olympia. The Complere Writings of an Italian Heretic, edited and trans., by Holt N. Parker. Chicago: University of Chicago, 2003.

Parker, Holt. "Morata Fulvia Olympia (1526/1527-1555)," Encyclopedia of Women in the Renaissance: Italy, French and England, Diana Robin, Anne R. Larsen, and Carole Levin, eds. Oxford: ABC CLIO, 2007.

Robin, Diana. "Renata di Francia (Renée de France, 1510-1574)," Encyclopedia of Women in the Renaissance: Italy, French and England. Oxford: ABC CLIO, 2007.

Robinson , C. Jeffrey Sr. "The Home is an Earthly Kingdom," Trained in the Fear of God. Randy Stinson \& Timothy Paul Jones. Ed,. Grand Rapids: Kregel, 2011.

Stjerna, Kirsi Irmeli, Women and the Reformation, Oxford: Blackwell Publishing, 2009. 
Thysell, Carol. The Pleasure of Discerment: Marguerite De Navarre as a Theologian. Oxford: University Press, 2000.

\section{INTERNET}

Carr, Simonetta. Olympia Morata: Champion of the Reformation. Diakses dari http://www.reformationitaly.org /2011/01 olympia-morata-champion-of-the reformation.

Febriana, Mariani. Lajang dalam Gereja dan Pelayanan.

Diakses dari http://sttaletheia.ac.id/wp-content/uploads/ 2015 /04/LAJANG-DALAM-GEREJA DAN-PELAYANAN-PdtMariani-Febriana.pdf

Gause, Ute, The Reformation war an educational movement for women, too. Diakses dari https://www.luther2017.de/en/ wiki/women-move-the-church-since-luthers-time/the-longway-to-pastoral-ministry-women-in-the-age-of-thereformation.

Langella , Christina, The Women of the Reformation Series at Heavenly Springs, diakses dari http://christinalangella.com /women-of-the-reformation-starting-october-31st

McWilliams, Barry. Women of the Reformation. Di akses dari http://www.eldrbarry.net/heidel/wivesref.pdf. 